\title{
Effect of ionotropic and metabotropic glutamate agonists and $D$-aspartate on prolactin release from anterior pituitary cells
}

\author{
M. Pampillo \\ S. Theas \\ B. Duvilanski \\ A. Seilicovich \\ M. Lasaga
}

\section{Summary}

Although the presence of ionotropic (iGluRs) and metabotropic (mGluRs) glutamate receptors has been demonstrated in the anterior pituitary, recent reports on the direct effect of glutamate on prolactin (PRL) secretion by anterior pituitary cells have presented contradictory results. Hence, the aim of this study was to determine the effect of ionotropic (iGluRs) and metabotropic (mGluRs) glutamate receptor agonists on prolactin (PRL) release. In addition, since D-Aspartate (D-Asp) is found in the pituitary and is involved in neuroendocrine regulation, we also studied the direct action of D-Asp on PRL secretion. Finally, since the posterior pituitary participates in the regulation of PRL secretion, we examined the influence of the posterior pituitary on the effects of NMDA and D-Asp on PRL release. - Glutamate $(1000 \mu \mathrm{M})$ increased PRL secretion from cultured anterior pituitary cells. Both NMDA $(100 \mu \mathrm{M})$ and kainate $(100 \mu \mathrm{M})$ increased PRL secretion and these effects were blocked by a specific NMDA receptor antagonist. AMPA did not modify PRL release in these cultures. The group I and II mGluR agonist, transACPD $(1000 \mu \mathrm{M})$, and a specific group II mGluR agonist, L-CCG-I (100-1000 $\mu \mathrm{M})$, inhibited whereas specific group I and III mGluR agonists, 3-HPG and L-AP4 respectively, had no effect on PRL release. Finally, D-Asp (100-1000 $\mu \mathrm{M})$ stimulated PRL secretion and this effect was reduced by a NMDA receptor antagonist. When anterior pituitary cells were cultured in the presence of posterior pituitary cells, NMDA did not modify PRL or GABA release, while D-Asp increased PRL secretion and decreased GABA release in these cocultures. - In conclusion, our results show that L-glutamate has a differential direct effect on PRL release: it exerts a stimulatory action via iGluRs and an inhibitory effect via mGluRs. D-Asp could directly stimulate PRL release through NMDA receptors. D-Asp may also stimulate PRL release by decreasing GABA release from the posterior pituitary.

\section{Key words}

Pituitary · Glutamate - Ionotropic receptors · Metabotropic receptors · D-aspartate · Prolactin

\section{Introduction}

Excitatory amino acids (EAAs) such as L-glutamate and Laspartate appear to be the major neurotransmitters in the brain (Brann et al., 1997). Glutamate binds to ionotropic (iGluRs) and metabotropic (mGluRs) receptors. iGluRs include $N$-methyl-Daspartate (NMDA), kainate (KA) and alpha-amino-3-hydroxy-5methyl-4-isoxazolepropionate (AMPA) receptor subtypes (Brann et al., 1997). The mGluRs are divided into three groups (I, II and III) based on agonist interactions and associated second messengers (Conn and Pin, 1997). Both ionotropic (NMDA, AMPA and
KA subtypes) and group II metabotropic receptors have been detected in the pituitary gland (Brann et al., 1997).

Glutamate is involved in several neuroendocrine functions, including the regulation of prolactin (PRL) secretion from the anterior pituitary. Its effects on PRL secretion appear to be influenced by age of the animal and endocrine milieu. The administration of NMDA receptor agonists increased PRL release in male (Gay and Plant, 1987) and female (Wilson and Knobil, 1982) monkeys, intact (Pohl et al., 1989) and orchidectomized male rats (Strobl et al., 1993) and cycling female rats (Pohl et al.,

Affiliation

Research Centre in Reproduction, School of Medicine, University of Buenos Aires, Buenos Aires, Argentina

Correspondence

Mercedes Lasaga · Centro de Investigaciones en Reproducción · Facultad de Medicina · Piso 10 .

Buenos Aires (1121) · Argentina ·T +54-11-5950-9612 ·F +54-11-4807-4052 ·e-mail: mlasaga@fmed.uba.ar

Received 01 June 2001 - First decision 20 July 2001 -Accepted 02 November 2001

Bibliography

Exp Clin Endocrinol Diabetes 2002; 110: 138 - 144 @ J.A. Barth Verlag in Georg Thieme Verlag KG .

ISSN 0947-7349 
1989). However, KA administration inhibited PRL secretion in neonatal, prepubertal and adult male rats (Pinilla et al., 1996) and AMPA administration decreased PRL release in prepubertal female and male rats (Gonzalez et al., 1999).

The mechanism by which glutamate affects PRL release remains unclear. It could involve mediation of PRL-releasing factors in the hypothalamus, such as TRH, VIP and oxytocin (OT), or of neurotransmitters, such as dopamine and GABA (Brann et al., 1997; Lasaga et al., 1998). Although the principal site of action of glutamate is the hypothalamus it can also act on lactotropes.

Contradictory results have been reported on the involvement of iGluRs on the direct effect of glutamate on PRL release from the pituitary. Login (1990) demonstrated that glutamate (1 mM) stimulated PRL release in primary cultures of dispersed female rat anterior pituitary cells studied in a perifusion protocol. This effect was abolished by [5R, 10S]-[+]-5-Methyl-10, 11-dihydro-5$H$-dibenzo[a,d] cyclo-hepten-5,10-imine hydrogen maleate (MK801), a selective non-competitive NMDA receptor antagonist, suggesting that NMDA receptors were involved. Conversely, Niimi et al. (1994) informed that neither glutamate, NMDA nor KA had any effect on PRL release from anterior pituitary cells of male rats studied by the reverse hemolytic plaque assay. However, recent investigations have found that high concentrations of both KA (1-10 mM) and NMDA (20 mM) inhibited PRL secretion from dispersed anterior pituitary cells obtained from 30-day-old male rats after $4 \mathrm{~h}$ of incubation (Pinilla et al., 1996; Aguilar et al., 1997).

Recent reports suggest the presence of a variety of D-aminoacids in mammalian tissues (Hashimoto and Oka, 1997). D-aspartate (D-Asp) has been found in nervous tissue and several endocrine glands (Hashimoto and Oka, 1997; Lee et al., 1999; Schell et al., 1997). In the pituitary gland, it has been detected in all three lobes (Schell et al., 1997), and its content increases throughout postnatal development up to adulthood (Hashimoto and Oka, 1997). This aminoacid occurs in high concentrations in the pituitary of adult rats as an endogenous compound (D'Aniello et al., 2000a) and it has been shown to be involved in the regulation of anterior pituitary hormone secretion (D'Aniello et al., 2000a). When administered in vivo to adult male rats, DAsp elicited an increase in serum levels of GH, LH, testosterone and progesterone (D’Aniello et al., 2000a). It has been demonstrated that DD-Asp has high affinity for the glutamate binding site of the NMDA receptor (Hashimoto and Oka, 1997), suggesting that it exerts its effects through interaction with this receptor subtype.

Since previous evidence on the direct actions of iGluR agonists on PRL release from the anterior pituitary is contradictory, the first aim of the present study was to investigate the effects of iGluR agonists on PRL release from cultured anterior pituitary cells of female rats. We also ran experiments to investigate the action of mGluRs and D-Asp on PRL release from anterior pituitary cells.

The rat posterior pituitary plays an essential role in regulating the release of PRL from the anterior pituitary (Frawley, 1994). The posterior pituitary communicates with the anterior pituitary via the short portal vessels, sending stimulatory (OT and $\alpha-\mathrm{MSH}$, among others) and inhibitory (GABA, dopamine) signals of PRL secretion (Kordon et al., 1994). We decided to evaluate the influence of the posterior pituitary on the effects of NMDA and DAsp on PRL secretion from the anterior pituitary. For this purpose, anterior pituitary cells were cultured in the presence of posterior pituitary cells, which are mainly intermediate lobe melanotrophs and neural lobe pituicytes (Dymshitz et al., 1991; O'Conner et al., 1996), although OT from nerve terminals has been determined to be present in cultured posterior pituitary cells (Laudon et al., 1990). The release of OT and GABA from these cocultures was also investigated, since both modulate PRL secretion from the anterior pituitary (Kordon et al., 1994).

\section{Materials and methods}

\section{Animals}

Adult intact female Wistar rats weighing 150-200 g were housed in a light (12 h light/dark cycle) and temperature-controlled environment and were provided with food and water ad libitum. The animals were kept according to the NIH Guide for the Care and Use of Laboratory Animals and sacrificed at random stages of the estrous cycle.

\section{Drugs}

Fetal bovine serum was obtained from GenSa, Buenos Aires, Argentina. MK-801 ([5R,10S]-[+]-5-Methyl-10,11-dihydro-5H-dibenzo[a,d]cyclo-hepten-5,10-imine hydrogen maleate) was purchased from RBI, Natick, MA, USA. Trans-ACPD ([ \pm$]$-1-aminocyclopentane-trans-1,3-dicarboxylic acid), AIDA ([RS]-1-aminoindan-1,5-dicarboxylic acid), L-AP4 (L(+)-2-Amino-4-phosphonobutyric acid), L-CCG-I ((2S, 1'S ,2'S)-2-(carboxycyclopropyl) glycine), AMPA (alpha-amino-3-hydroxy-5-methyl-4-isoxazolepropionate) and 3-HPG ([+]- $\alpha$-amino-3-hydroxy-benzeneacetic acid) were obtained from Tocris Cookson Inc., Ballwin, MO, USA. OT was purchased from Peninsula Laboratories Inc., Belmont, CA, USA, and ${ }^{125}$ I radionucleide and $\left[{ }^{3} \mathrm{H}\right]$ muscimol were purchased from New England Nuclear Co., Boston, MA, USA. L-Glutamic acid, NMDA ( $N$-methyl-D-aspartate), D-Asp (D-aspartic acid), KA (Kainate), DNQX (6,7-dinitroquinoxaline-2,3-(1H,4H)-dione) and all other media and supplements were obtained from Sigma Chemical Co., St Louis, MO, USA.

\section{Anterior pituitary cell culture}

Anterior pituitary glands (posterior pituitaries removed) or whole pituitary glands were obtained within minutes after decapitation. The glands were washed several times with Dulbecco's Modified Eagle's medium (DMEM) and cut into small fragments. Sliced fragments were dispersed enzymatically by succesive incubations with $5 \mathrm{mg} / \mathrm{ml}$ trypsin (Type XII-S from bovine pancreas), $1 \mathrm{mg} / \mathrm{ml}$ DNAse (Deoxyribonuclease II, Type $\mathrm{V}$ from bovine spleen), and $1 \mathrm{mg} / \mathrm{ml}$ trypsin inhibitor (Type II-S from soybean) in DMEM supplemented with $3 \mathrm{mg} / \mathrm{ml}$ bovine serum albumin (BSA). The cells were finally dispersed mechanically by extrusion through a Pasteur pipette in Krebs buffer without calcium and magnesium. Dispersed cells were washed twice and suspended in DMEM supplemented with $10 \mu \mathrm{l} / \mathrm{ml}$ MEM aminoacids, $5.6 \mu \mathrm{g} / \mathrm{ml}$ amphotericin B, $25 \mu \mathrm{g} / \mathrm{ml}$ gentamicin and $2 \mathrm{mM}$ glutamine (DMEM-S). Cell viability as assessed by trypan blue exclusion was above $90 \%$. The cells were seeded onto 96-well tissue culture plates at a density of 80000 cells $/ 0.2 \mathrm{ml} /$ well (anterior pituitary cell culture) or onto 48-well tissue 
culture plates at a density of 250000 cells $/ 0.5 \mathrm{ml} /$ well (anterior and posterior pituitary cell culture) and cultured for $72 \mathrm{~h}\left(37^{\circ} \mathrm{C}\right.$, $5 \% \mathrm{CO}_{2}-95 \% \mathrm{O}_{2}$ in air) in DMEM-S with $10 \%$ fetal bovine serum. After the culture period, cells were washed twice with Krebs Ringer bicarbonate buffer (KRB) $(118.46 \mathrm{mM} \mathrm{NaCl}, 5 \mathrm{mM} \mathrm{KCl}$, $2.5 \mathrm{mM} \mathrm{CaCl}, 1.18 \mathrm{mM} \mathrm{NaH} \mathrm{PO}_{4}, 1.18 \mathrm{mM} \mathrm{MgSO}, 24.88 \mathrm{mM}$ $\mathrm{NaHCO}_{3}$, pH 7.4) containing $10 \mathrm{mM}$ glucose and $10 \mathrm{mM}$ Hepes, and incubated for $4 \mathrm{~h}$ in KRB alone or plus test substances. At the end of the incubation period, the media were aspirated and stored at $-20^{\circ} \mathrm{C}$ until assayed for PRL or GABA or at $-70^{\circ} \mathrm{C}$ until assayed for OT.

\section{PRL radioimmunoassay}

PRL was measured by a double-antibody radioimmunoassay with reagents provided by The National Hormone and Pituitary Program. RP-3 was used as reference preparation and NIDDKanti-rPRL-S-9 as antiserum ( $\left.\mathrm{ED}_{50}: 0.54 \mathrm{RP}-3\right)$. The cross-reactivity with other pituitary hormones was negligible. The intra and interassay coefficients of variation were less than $10 \%$. PRL concentration was expressed as ng/well.

\section{cAMP determination}

In order to determine cAMP formation, anterior pituitary cells were seeded onto 48 -well tissue culture plates at a density of 250 $000 / 0.5 \mathrm{ml} /$ well. After the culture period, cells were washed twice with KRB and incubated for $10 \mathrm{~min}$ in $0.5 \mathrm{ml}$ of KRB alone or plus test substances. Enzymatic activity was stopped by heating for $5 \mathrm{~min}$ at $100^{\circ} \mathrm{C}$ in $50 \mathrm{mM}$ sodium acetate buffer, $\mathrm{pH}$ 6.2. Finally, the cells were sonicated and stored at $-70^{\circ} \mathrm{C}$ until assayed for cAMP. cAMP concentration was determined by radioimmunoassay using ${ }^{125} \mathrm{I}-\mathrm{CAMP}$ as tracer and anti-cAMP antiserum (NIDDK, final dilution $1: 50000$ ). The reaction was stopped with cold 2\% albumin in PBS buffer followed by $96 \%$ ethanol. The intrassay and interassay coefficients of variation were less than $9 \%$ and $11 \%$ respectively, and assay sensitivity was $9.75 \mathrm{fmol} /$ tube. cAMP content was expressed as pmol/well.

\section{GABA analysis}

Aliquots of the coculture incubation medium were stored at $-20^{\circ} \mathrm{C}$ until GABA concentration was determined by the $\left[{ }^{3} \mathrm{H}\right]$ muscimol radioreceptor assay described by Bernasconi et al. (Bernasconi et al., 1980). This method measures the concentration of endogenous GABA and other $G_{A B A}$ receptor ligands metabolically related to GABA (sensitivity range: $12.5-200 \mathrm{pmol} / \mathrm{ml}$ ). GABA concentration in the media was expressed as pmol/well.

\section{Oxytocin determination}

Oxytocin concentration in the incubation medium of the cocultures was measured on duplicate samples by radioimmunoassay using ${ }^{125}$ I-oxytocin as tracer and anti-oxytocin antiserum (Sigma Chemical Co., final dilution $1: 36$ ) as described elsewhere (De Laurentiis et al., 2000). Oxytocin was used both as standard preparation and for iodination with ${ }^{125}$ I. The reaction was stopped with cold $2 \%$ albumin in PBS buffer followed by $96 \%$ ethanol. The intrassay coefficient of variation was less than $9 \%$, and assay sensitivity was $7 \mathrm{pg} /$ tube. Oxytocin concentration was expressed as $\mathrm{pg} /$ well.

\section{Statistical analysis}

Data were expressed as mean \pm S.E.M. and were analyzed by unpaired Student's t-test, one-way analysis of variance (ANOVA) followed by Dunnett's test or Student-Newman-Keuls Multiple Comparisons Test, or two-way ANOVA with interaction terms. Differences with a $\mathrm{p}$ value of less than 0.05 were considered statistically significant.

\section{Results}

\section{Effect of glutamate, iGluR and mGluR agonists on PRL release from anterior pituitary cells}

Glutamate $(1000 \mu \mathrm{M})$ significantly increased PRL release from cultured anterior pituitary cells (Fig. 1). NMDA (10-100 $\mu \mathrm{M})$ stimulated PRL release from these cells (Fig. 2). MK-801 (10 $\mu \mathrm{M})$, a selective non-competitive NMDA receptor antagonist, blocked the stimulatory effect of NMDA (Fig. 2). KA (1-100 $\mu \mathrm{M})$ also significantly stimulated PRL release (Fig. 3). DNQX $(10 \mu \mathrm{M})$, a specific non-NMDA receptor antagonist, was unable to block the KA effect (Fig. 3). However, the stimulatory effect of KA $(100 \mu \mathrm{M})$

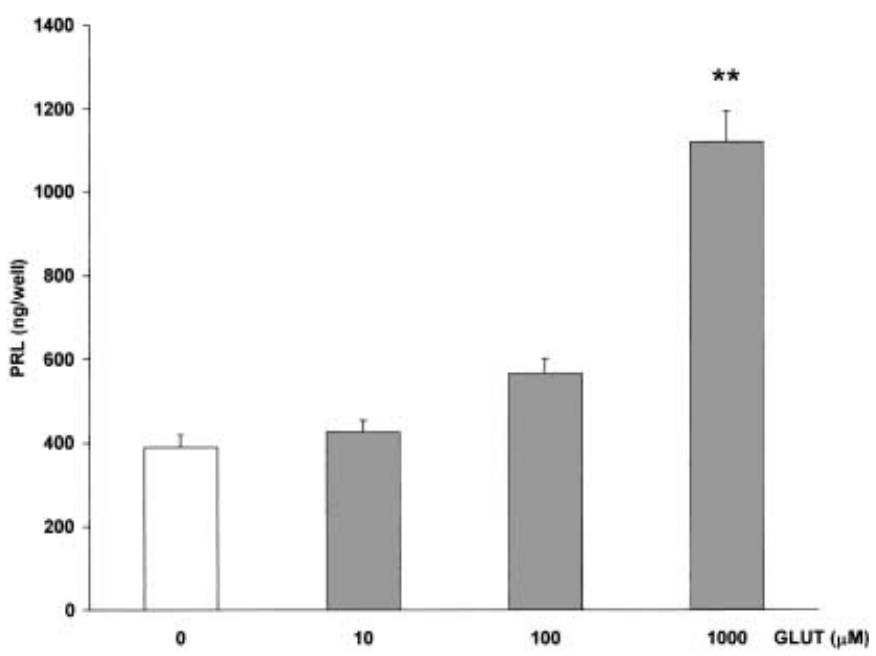

Fig. 1 Effect of L-Glutamate (GLUT) on PRL release from anterior pituitary cells. Values represent mean \pm S.E.M. of 5-6 determinations per group. Data were evaluated by one-way ANOVA followed by Dunnett's test.

${ }^{* *} \mathrm{p}<0.01$ vs control

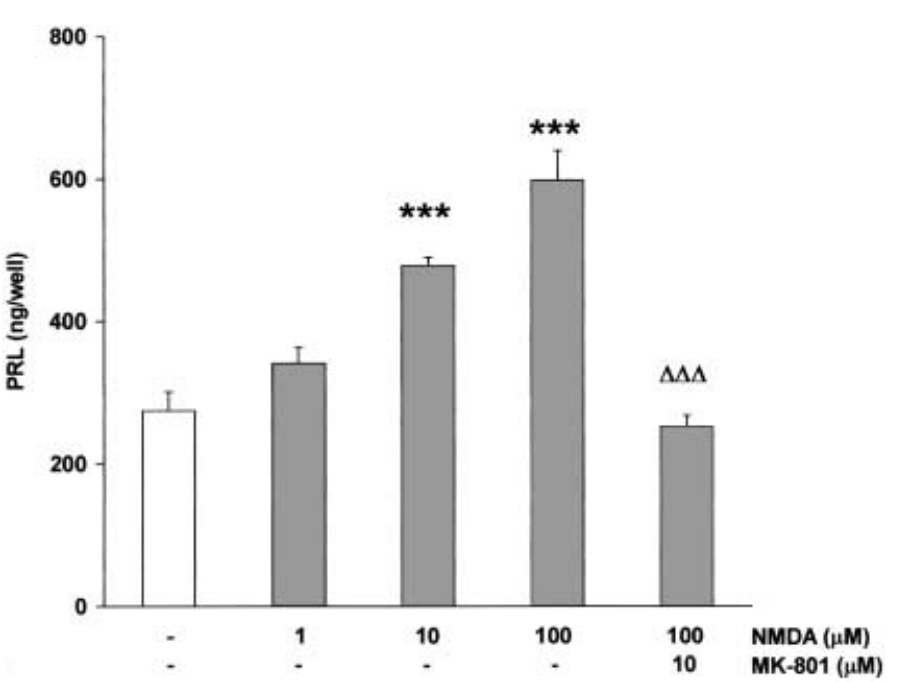

Fig. 2 Effect of NMDA and MK-801 (a NMDA receptor antagonist) on PRL release from anterior pituitary cells. Values represent mean \pm S.E.M. of 4-6 determinations per group. Data were evaluated by one-way ANOVA followed by Student Newman Keuls Multiple Comparisons Test.

*** $\mathrm{p}<0.001$ vs control

$\Delta \Delta \Delta \quad \mathrm{p}<0.001$ vs NMDA $100 \mu \mathrm{M}$ 


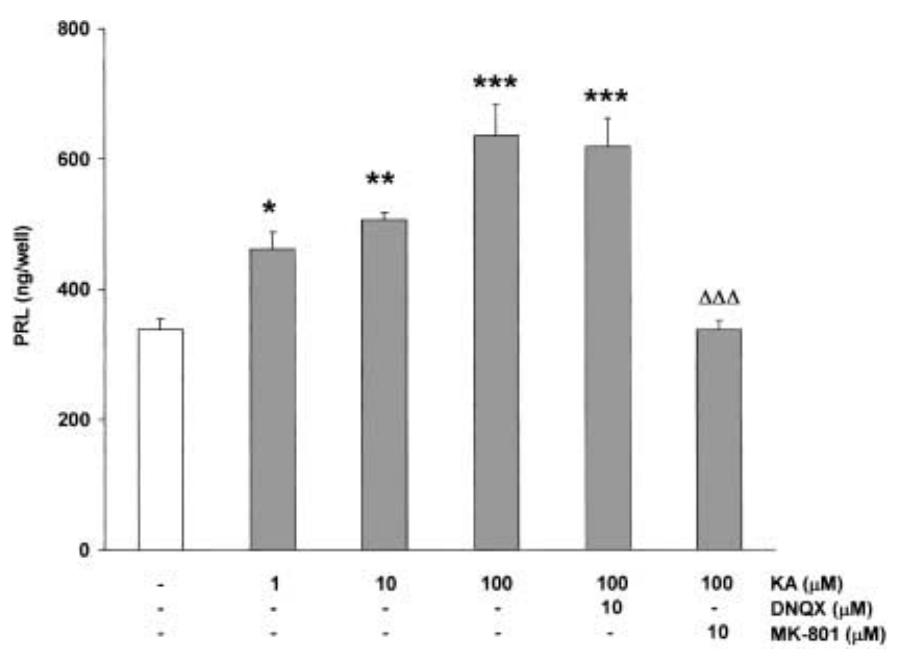

Fig. 3 Effect of KA, DNQX (a KA/AMPA receptor antagonist) and MK-801 (a NMDA receptor antagonist) on PRL release from anterior pituitary cells. Values represent mean \pm S.E.M. of 4-6 determinations per group. Data were evaluated by one-way ANOVA followed by Student Newman Keuls Multiple Comparisons Test.

$\mathrm{p}<0.05 ;{ }^{* *} \mathrm{p}<0.01 ;{ }^{* * *} \mathrm{p}<0.001$ vs control

$\Delta \Delta \Delta \mathrm{p}<0.001$ vs KA $100 \mu \mathrm{M}$

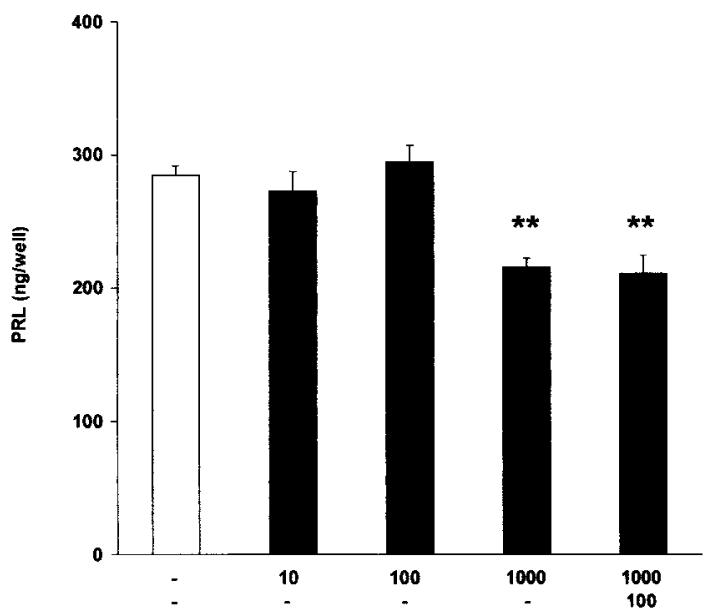

trans-ACPD ( $\mu \mathrm{M})$ ADA $(\mu \mathrm{M})$

Fig. 4 Effect of trans-ACPD (a group I and II mGluR agonist) and AIDA (a group I mGluR antagonist) on PRL release from anterior pituitary cells. Values represent mean \pm S.E.M. of 5-6 determinations per group. Data were evaluated by one-way ANOVA followed by Student Newman Keuls Multiple Comparisons Test.

** $\mathrm{p}<0.01$ vs control

on PRL release was inhibited by MK-801 (10 $\mu \mathrm{M})$ (Fig. 3). On the contrary, AMPA did not modify hormone release at any concentration tested (Control: $447.5 \pm 9.8 \mathrm{ng}$ PRL/well; $1 \mu \mathrm{M}$ AMPA: $424.6 \pm 25.1 ; 10 \mu \mathrm{M}$ AMPA: $443.4 \pm 27.6 ; 100 \mu \mathrm{M}$ AMPA: $507.1 \pm$ $30.3 ; n=5-6)$.

The non selective group I and II mGluR agonist, trans-ACPD $(1000 \mu \mathrm{M})$, inhibited PRL release from anterior pituitary cells (Fig. 4). AIDA (100 $\mu \mathrm{M})$, a group I mGluR antagonist, did not affect the inhibitory effect of trans-ACPD (Fig. 4). 3-HPG, a group I mGluR agonist, had no effect on PRL release (Control: $411.2 \pm$ 17.6 ng PRL/well; $1 \mu \mathrm{M}$ 3-HPG: 452.9 $\pm 27.5 ; 10 \mu \mathrm{M}$ 3-HPG: 419.8 \pm 28.9 ; $100 \mu \mathrm{M}$ 3-HPG: $425.8 \pm 26.9 ; n=5-7)$, whereas L-CCG-I, a group II mGluR agonist $(10-1000 \mu \mathrm{M})$, significantly reduced it (Fig. 5). Group II mGluR activation leads to an inhi$\vec{\omega}$ bition of adenylate cyclase activity in several tissues (Conn and Pin, 1997). cAMP production was measured in anterior

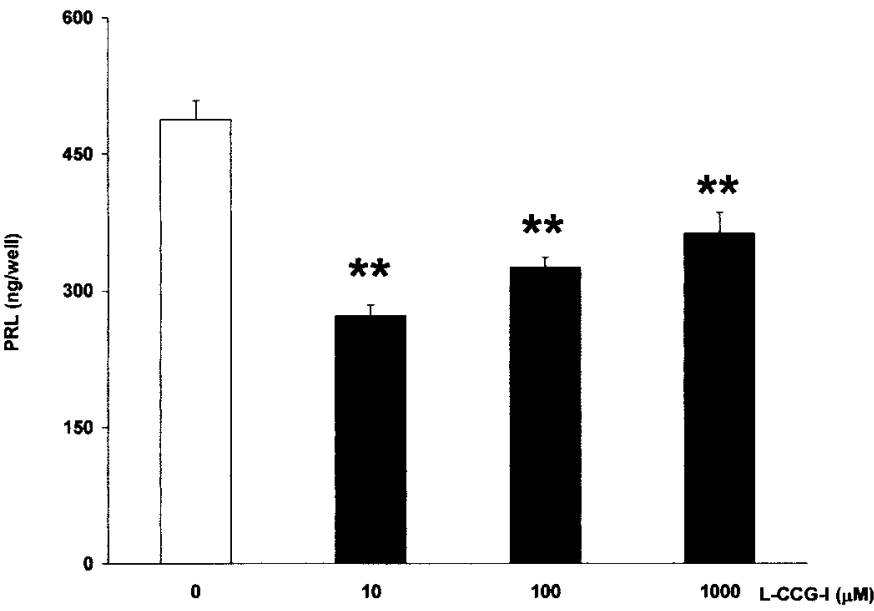

Fig. 5 Effect of L-CCG-I (a group II mGluR agonist) on PRL release from anterior pituitary cells. Values represent mean \pm S.E.M. of 6-7 determinations per group. Data were evaluated by one-way ANOVA followed by Dunnett's test.

${ }^{* *} \mathrm{p}<0.01$ vs control

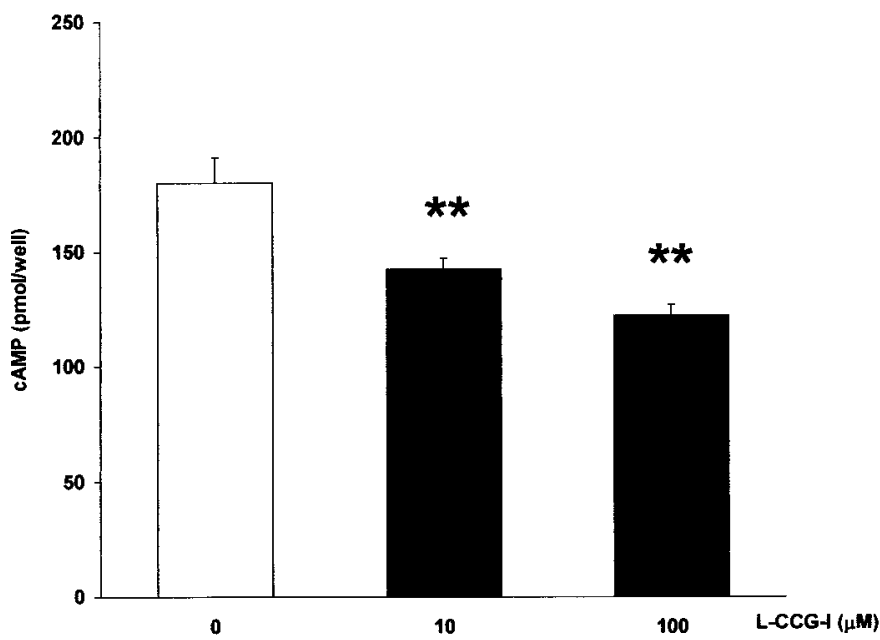

Fig. 6 Effect of L-CCG-I (a group II mGluR agonist) on CAMP content in anterior pituitary cells. Values represent mean \pm S.E.M. of 6 determinations per group. Data were evaluated by one-way ANOVA followed by Dunnett's test. ${ }_{* *} \mathrm{p}<0.01$ vs control

mGluR agonist significantly decreased cAMP content in these cells (Fig. 6). L-AP4, a selective group III mGluR agonist, failed to modify PRL release (Control: $379.6 \pm 9.6 \mathrm{ng}$ PRL/well; $100 \mu \mathrm{M}$ L-AP4: $373.7 \pm 26.3 ; 1000 \mu \mathrm{M}$ L-AP4: $425.1 \pm 12.5 ; \mathrm{n}=$ 5-6).

\section{Effect of NMDA on PRL release from cocultures of anterior and posterior pituitary cells}

To study the influence of the posterior pituitary on the effect of NMDA on PRL release, anterior pituitary cells were cultured with posterior pituitary cells. NMDA did not affect PRL release from these cocultures (Control: $2989.8 \pm 205.8 \mathrm{ng}$ PRL/well; $100 \mu \mathrm{M}$ NMDA: $2768.7 \pm 102.3 ; n=6$ ). To investigate whether NMDA was affecting the release of posterior pituitary factors involved in the regulation of PRL release, we studied the effect of NMDA $(100 \mu \mathrm{M})$ on OT and GABA release from these cells. NMDA did not modify GABA release (Control: $47.2 \pm 1.6$ pmol GABA/well; $100 \mu$ M NMDA: $45.2 \pm 2.6 ; n=4-5)$, and induced a non significant 


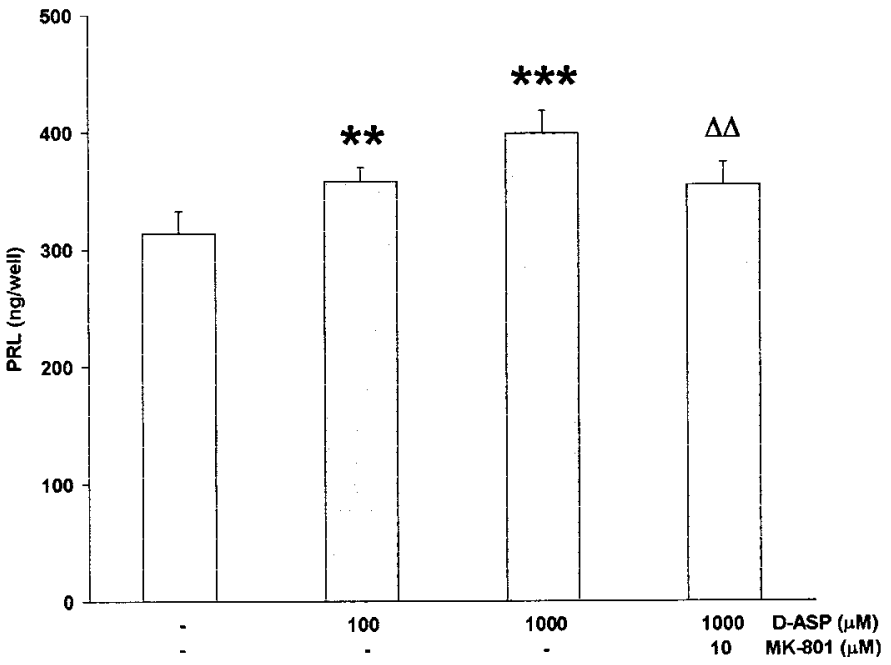

Fig. 7 Effect of D-ASP and MK-801 (a NMDA receptor antagonist) on PRL release from anterior pituitary cells. Values represent mean \pm S.E.M. of 5-8 determinations per group. Data were evaluated by one-way ANOVA followed by Student Newman Keuls Multiple Comparisons Test.

** $\mathrm{p}<0.01 ;{ }^{* * *} \mathrm{p}<0.001$ vs control

$\Delta \Delta \mathrm{p}<0.01$ vs D-ASP $1000 \mu \mathrm{M}$

decrease in OT release (Control: $420.4 \pm 83.8 \mathrm{pg}$ OT/well; $100 \mu \mathrm{M}$ NMDA: $247.5 \pm 47.4 ; \mathrm{n}=4-5)$.

Effect of D-Asp on PRL release from anterior pituitary cells or from cocultures of anterior and posterior pituitary cells

D-Asp $(100-1000 \mu \mathrm{M})$ increased PRL release from anterior pituitary cells (Fig. 7). The increase in PRL release induced by D-Asp $1000 \mu \mathrm{M}$ was reduced by the addition of MK-801 $(10 \mu \mathrm{M})$ to the incubation medium (Fig. 7). We also studied the effect of this D-aminoacid on cocultures of anterior and posterior pituitary cells. D-Asp elicited an increase in PRL release, while it induced a decrease in GABA release from these cells (Table $\mathbf{1}$ ). D-Asp induced a non significant decrease in OT concentration in the coculture medium (Table $\mathbf{1}$ ).

\section{Discussion}

The involvement of glutamate in the regulation of PRL secretion has been demonstrated in different experimental models and several species (Brann et al., 1997). iGluR antagonists blocked the preovulatory or suckling-induced increase in plasma PRL levels in the female rat (Parker and Crowley, 1993; Brann and Mahesh, 1991; Brann et al., 1993), suggesting that glutamate plays a physiological role in the regulation of PRL secretion. However, it has not been fully elucidated whether glutamate stimulation of
PRL release involves only the mediation of hypothalamic factors or if there is also direct action at the pituitary level. The literature provides weak and controversial data concerning a direct role of glutamate on PRL release from the anterior pituitary.

The present study demonstrates that glutamate may have a dual direct effect on PRL release from anterior pituitary cells of female rats: it exerts a stimulatory action when it interacts with iGluRs, while it has an inhibitory effect when it activates group II mGluRs. This may explain why glutamate had a stimulatory effect on PRL release from anterior pituitary cells of female rats only at the highest concentration tested. This result is in line with the glutamate induced stimulation of PRL release from female rat anterior pituitary cells observed by Login (1990). Since we were able to block the stimulatory effect of NMDA with the antagonist MK-801, our study also lends support to the suggested involvement of NMDA receptors in this effect of glutamate on PRL release (Login, 1990). KA also increased PRL secretion. However, KA-induced stimulation of PRL release was not antagonized by DNQX, a KA/AMPA receptor antagonist, though it was blocked by MK-801. Studies by Henley et al. (Henley et al., 1992) in Xenopus brain suggested that subunit interchanges can occur between non-NMDA and certain NMDA receptor subunits, giving rise for example to a hybrid unitary KA/AMPA/NMDA receptor. In our cultures, KA could be acting through a receptor that might also have affinity for NMDA, since the KA effect on PRL release was reversed by MK-801. It should be noted that similar results were reported by Zanisi et al. (1994) and by Costa et al. (1992), who observed that the KA effect on hormone secretion was reduced by DL-2-amino-5-phosphonovaleric acid (AP-5), a NMDA antagonist.

Group II mGluRs were detected in the anterior lobe of the pituitary gland (Petralia et al., 1996). The existence of other groups of mGluRs in this gland has not been studied yet. TransACPD, a non selective group I and II mGluR agonist, decreased PRL release from anterior pituitary cells of female rats. Since AIDA, a specific group I mGluR antagonist, was unable to reverse the inhibitory effect of trans-ACPD, our data suggest that the trans-ACPD inhibitory effect would be mediated by group II mGluRs. This hypothesis is supported by the fact that 3-HPG, a specific group I mGluR agonist, did not modify PRL release, whereas L-CCG-I, a specific group II mGluR agonist, mimicked the inhibition induced by trans-ACPD. Group II mGluRs act through an inhibition of adenylate cyclase activity (Conn and Pin, 1997). Since L-CCG-I decreased cAMP levels in anterior pituitary cells, our results suggest that group II mGluRs are involved in the glutamate inhibitory effect on PRL release by inhibiting adenylate cyclase activity. Our data also suggest that group I and III mGluRs are not involved in the regulation of PRL secretion.

Table 1 Effect of D-ASP on PRL, GABA and oxytocin release from cocultures of anterior and posterior pituitary cells. Values represent mean \pm S.E.M. Data were evaluated by one-way ANOVA followed by Dunnett's test.

\begin{tabular}{llll}
\hline & PRL (ng/well) & GABA (pmol/well) & OXYTOCIN (pg/well) \\
\hline CONTROL & $2712.5 \pm 59.7(6)$ & $62.3 \pm 4.2(7)$ & $475.2 \pm 63.4(4)$ \\
\hline D-ASP $100 \mu M$ & $3116.7 \pm 96.7(6)^{*}$ & $52.1 \pm 4.1(6)$ & $397.4 \pm 58.5(5)$ \\
D-ASP $1000 \mu M$ & $3068.3 \pm 113.0(5)^{*}$ & $43.8 \pm 2.5(6)^{* *}$ & $302.9 \pm 74.6(5)$ \\
\hline
\end{tabular}

${ }^{*} \mathrm{p}<0.05$ vs control; ${ }^{* *} \mathrm{p}<0.01$ vs control 
It is unlikely that the effect of ionotropic agonists on prolactin release may result from a toxic action on anterior pituitary cells, since we found that NMDA up to $1 \mathrm{mM}$ did not affect cell viability as assessed by the MTT cytotoxicity assay (data not shown). Moreover, trans-ACPD $(1000 \mu \mathrm{M})$ and L-CCG-I $(10-1000 \mu \mathrm{M})$ did not modify LH release from anterior pituitary cells, indicating that their effect on PRL release is specific (data not shown). The specificity of the action of these compounds also indicates the absence of cellular toxicity.

Glutamate is not only an excitatory neurotransmitter but also an important aminoacid in intermediate metabolism. The serum level of glutamate is about $50-100 \mu \mathrm{M}$ in normal conditions (Meldrum et al., 2000), a concentration similar to those used in our experiments. Although glutamate concentration in blood from portal vessels has not been reported, it is possible that it could be significantly higher than in peripheral blood because of glutamate released from hypothalamic terminals. Therefore, glutamate could be considered an important factor in the control of prolactin release in physiological conditions, through its action on lactotrophs. Moreover, glutamate could also be relevant in certain pathological conditions such as migraine or amyotropic lateral sclerosis, in which serum glutamate levels can be higher than in normal conditions (Perry et al., 1990; Ferrari et al., 1990).

Recent studies suggest a role for D-Asp in neuroendocrine modulation (Lee et al., 1999; Schell et al., 1997; D’Aniello et al., 2000a). This D-aminoacid has been localized in the anterior, intermediate and posterior lobes of the pituitary gland of adult rats (Schell et al., 1997). While we were finishing our study, D'Aniello et al. (D'Aniello et al., 2000b) reported that D-Asp increased PRL secretion from isolated anterior pituitaries of male rats. Our results for cells from female rats tally with their data. DAsp increased PRL release and its effect was reduced by MK-801. NMDA receptors have been localized in PRL-producing cells in the anterior pituitary (Brann et al., 1997) and D-Asp may act through NMDA receptors (Hashimoto and Oka, 1997). Therefore, D-Asp could directly modify PRL release by binding to the NMDA receptor.

The posterior pituitary contributes to the regulation of PRL secretion, sending inhibitory and stimulatory factors to the anterior pituitary (Kordon et al., 1994). Both dopamine and GABA reach the anterior pituitary through the short portal vessels and inhibit PRL release from lactotropes (Kordon et al., 1994; Neill and Nagy, 1994). Also, a number of peptides such as OT and $\alpha-$ MSH are released from the posterior pituitary and stimulate PRL secretion (Kordon et al., 1994). Both NMDA receptors and D-Asp are present in the rat posterior pituitary (Meeker et al., 1994; Schell et al., 1997). High basal release of PRL in our cocultures of anterior and posterior pituitary cells is probably due to both a greater number of anterior pituitary cells and the presence of a PRL releasing factor (PRF) secreted by posterior pituitary cells (Laudon et al., 1990). This PRF would be released from melanotrophs or a small subpopulation of nonopioid-producing cells of the intermediate lobe of the pituitary, and its activity would remain relatively stable in cultures of posterior pituitary cells (Laudon et al., 1990). NMDA does not modify PRL release from anterior pituitary cells cocultured with posterior pituitary cells. The possibility that a lack of effect of NMDA on PRL release in this condition might be due to high PRL levels in the incubation medium was discarded, since cocultured cells still responded to TRH (data not shown). We previously demonstrated that NMDA increased GABA release (Pampillo et al., 1999) and decreased OT secretion (unpublished data) from isolated rat posterior pituitary. In the cocultures of anterior and posterior pituitary cells, NMDA did not alter GABA release, but showed a tendency to decrease OT secretion. Therefore, other inhibitory posterior pituitary factors, such as dopamine, could be released by NMDA, blocking its direct stimulatory effect on PRL release. We have also observed that D-Asp decreases GABA and OT release from isolated posterior pituitaries (unpublished data). D-Asp also had a slight inhibitory effect on OT release in cocultures. However, it significantly inhibited GABA release. Since GABA plays an important inhibitory role in PRL release, the inhibitory effect of D-Asp on GABA release may contribute to its stimulatory action on PRL release.

In summary, L-glutamate has a direct differential effect on PRL release. It exerts stimulatory action acting via ionotropic receptors and an inhibitory effect through metabotropic receptors. On the other hand, D-Asp could directly stimulate PRL release through NMDA receptors. Our data also indicate that DAsp may play a role in mediating posterior pituitary neurotransmitter release such as GABA, which subsequently influences PRL secretion.

Acknowledgments: The authors wish to thank the NIH for providing prolactin and cAMP kits. They also thank Dr. Omar Pignataro from IByME, Argentina, for supplying labeled cAMP. This work was funded by grants from the Consejo Nacional de Investigaciones Científicas y Técnicas (CONICET), Fundación Antorchas, Universidad de Buenos Aires and the Agencia Nacional de Promoción Científica y Tecnológica, Argentina.

\section{References}

${ }^{1}$ Aguilar E, Tena-Sempere M, Aguilar R, González D, Pinilla L. Interactions between $N$-methyl-D-aspartate, nitric oxide and serotonin in the control of prolactin secretion in prepubertal male rats. Eur J Endocrinology 1997; 137: 99 - 106

2 Bernasconi R, Bittiger H, Heid J, Martin P. Determination of GABA levels by a 3H-muscimol-radioreceptor assay. J Neurochem 1980; 34: 614 618

${ }^{3}$ Brann DW, Mahesh VB. Endogenous excitatory amino acid involvement in the preovulatory and steroid-induced surge of gonadotropins in the female rat. Endocrinology 1991; 128: 1541 - 1547

${ }^{4}$ Brann DW, Mahesh VB. Excitatory amino acids: evidence for a role in the control of reproduction and anterior pituitary hormone secretion. Endocrine Rev 1997; 18: 678 - 700

${ }^{5}$ Brann DW, Ping L, Mahesh VB. Possible role of non-NMDA receptormediated neurotransmission in steroid-induced and preovulatory gonadotropin surges in the rat. Mol Cell Neurosci 1993; 4: 292 - 297

${ }^{6}$ Conn JP, Pin JP. Pharmacology and functions of metabotropic glutamate receptors. Annu Rev Pharmacol Toxicol 1997; 37: 205 - 237 Costa A, Yasin SA, Hucks D, Forsling ML, Besser GM, Grossman A. Differential effects of neuroexcitatory amino acids on corticotropinreleasing hormone-41 and vasopressin release from rat hypothalamic explants. Endocrinology 1992; 131: 2595 - 2602

${ }^{8}$ D'Aniello A, Di Fiore MM, Fisher GH, Milone A, Seleni A, D'Aniello S, Perna AF, Ingrosso D. Occurrence of D-aspartic acid and $N$-methyl-Daspartic acid in rat neuroendocrine tissues and their role in the modulation of luteinizing homone and growth hormone release. FASEB J 2000a; 14: 699 - 714

${ }^{9}$ D'Aniello G, Tolino A, D'Aniello A, Errico F, Fisher GH, Di Fiore MM. The role of $\mathrm{D}$-aspartic acid and $N$-methyl-D-aspartic acid in the regulation of prolactin release. Endocrinology 2000b; 141: $3862-3870$ 
${ }^{10}$ De Laurentiis A, Pisera D, Duvilanski B, Rettori V, Lasaga M, Seilicovich A. Neurokinin A inhibits oxytocin and GABA release from the posterior pituitary by stimulating nitric oxide synthase. Brain Res Bul 2000; 53: $325-330$

${ }^{11}$ Dymshitz J, Ben-Jonathan N. Coculture of anterior and posterior pituitary cells: selective stimulation of lactotrophs. Endocrinology 1991; 128: 469 - 2475

${ }^{12}$ Ferrari MD, Odink J, Bos KD, Malessey MJA, Bruyn GW. Neuroexcitatory plasma amino acids are elevated in migraine. Neurology 1990; 40: 1582 - 1586

${ }^{13}$ Frawley LS. Role of the hypophyseal neurointermediate lobe in the dynamic release of prolactin. Trends Endocrinol Metab 1994; 5: 107 112

${ }^{14}$ Gay VL, Plant TM. N-methyl-D,L-aspartate elicits hypothalamic gonadotropin-releasing hormone release in prepubertal male rhesus monkeys. Endocrinology 1987; 120: 2289 - 2296

${ }^{15}$ Gonzalez LC, Pinilla L, Tena-Sempere M, Aguilar E. Role of $\alpha$-amino-3hydroxy-5-methylisoxazole-4-propionic acid receptors in the contro of prolactin, growth hormone and gonadotropin secretion in prepubertal rats. J Endocrinol 1999; 162: 417 - 424

${ }^{16}$ Hashimoto A, Oka T. Free D-aspartate and D-serine in the mammalian brain and periphery. Prog Neurobiol 1997; 52: 325 - 353

${ }^{17}$ Henley JM, Ambrosini A, Rodriguez-Ithurralde D, Sudan H, Brackley P, Kerry C, Mellor I, Abutidze K, Usherwood PNR, Barnard EA. Purified unitary kainate/ $\alpha$-amino-3-hydroxy-5-methylisooxazole-propionate (AMPA) and kainate/AMPA/N-methyl-D-aspartate receptors with interchangeable subunits. Proc Natl Acad Sci USA 1992; 89: 4806 4810

${ }^{18}$ Kordon C, Drouva SV, Martinez de la Escalera G, Weiner RI. Role of classic and peptide neuromediators in the neuroendocrine regulation of luteinizing hormone and prolactin. In: Knobil E, Neill JD (eds) The physiology of Reproduction, Second Edition, Raven Press, New York 1994; 1621 - 1682

${ }^{19}$ Lasaga M, De Laurentiis A, Pampillo M, Pisera D, Díaz M, Theas S, Duvilanski B, Seilicovich A. The effect of excitatory aminoacids on GABA release from mediobasal hypothalamus of female rats. Neurosci Lett 1998; 247: $119-122$

${ }^{20}$ Laudon M, Grossman DA, Ben-Jonathan N. Prolactin-releasing factor: cellular origin in the intermediate lobe of the pituitary. Endocrinology 1990; 126: 3185 - 3192

${ }^{21}$ Lee J, Homma H, Tashiro K, Iwatsubo T, Imai K. D-aspartate localization in the rat pituitary gland and retina. Brain Res 1999; 838: 193 - 199

${ }^{22}$ Login IS. Direct stimulation of pituitary prolactin release by glutamate. Life Sci 1990; 47: 2269 - 2275

${ }^{23}$ Meeker RB, Greenwood RS, Hayward JN. Glutamate receptors in the rat hypothalamus and pituitary. Endocrinology 1994; 134: 621 - 629
24 Meldrum BS. Glutamate as a neurotransmitter in the brain: review of physiology and pathology. J Nutr 2000; 130: 1007S - 15S

${ }^{25}$ Neill JD, Nagy GM. Prolactin secretion and its control. In: Knobil E, Neill JD (eds) The physiology of Reproduction, Second Edition., Raven Press, New York 1994; 1833 - 1860

${ }^{26}$ Niimi M, Sato M, Murao K, Takahara J, Kawanishi K. Effect of excitatory amino acid receptor agonists on secretion of growth hormone as assessed by the reverse hemolytic plaque assay. Neuroendocrinology 1994; 60: 173 - 178

${ }^{27}$ O'Conner JL, Wade MF. Evidence that the posterior pituitary plays a role in neuropeptide $\mathrm{Y}$ and luteinizing hormone-releasing hormonestimulated gonadotropin secretion in vitro. Proc Soc Exp Biol Med 1996; 213: 59 - 64

${ }^{28}$ Pampillo M, De Laurentiis A, Duvilanski B, Pisera D, Díaz MC Seilicovich A, Lasaga M. NMDA receptor-mediated control of GABA release from neurointermediate lobes of female and male rats. Brain Res 1999; 842: $469-472$

${ }^{29}$ Parker SL, Crowley WR. Stimulation of oxytocin release in the lactating rat by central excitatory amino acid mechanisms: evidence for specific involvement of $R, S$ - $\alpha$-amino-3-hydroxy-5-methylisoxazole-4-propionic acid-sensitive glutamate receptors. Endocrinology 1993; 133: $2847-2854$

${ }^{30}$ Perry TL, Krieger C, Hansen S, Eisen A. Amyotrophic lateral sclerosis: amino acid levels in plasma and cerebrospinal fluid. Ann Neurol 1990; 28: $12-17$

${ }^{31}$ Petralia RS, Wang YX, Niedzielski AS, Wenthold RJ. The metabotropic glutamate receptors, mGluR2 and mGluR3, show unique postsynaptic, presynaptic and glial localizations. Neuroscience 1996; 71: 949 - 976

32 Pinilla L, González D, Tena-Sempere M, Aguilar R, Aguilar E. Mechanisms of inhibitory action of kainic acid on prolactin secretion in male rats. J Endocrinol 1996; 151: 159 - 167

${ }^{33}$ Pohl CR, Lee LR, Smith MS. Qualitative changes in luteinizing hormone and prolactin responses to $\mathrm{N}$-methyl-aspartic acid during lactation in the rat. Endocrinology 1989; 124: 1905 - 1911

${ }^{34}$ Schell MJ, Cooper OB, Snyder SH. D-aspartate localizations imply neuronal and neuroendocrine roles. Proc Natl Acad Sci USA 1997; 94: $2013-2018$

${ }^{35}$ Strobl FJ, Luderer U, Besecke L, Wolfe A, Schwartz NB, Levine JE Differential gonadotropin responses to $N$-methyl-D,L-aspartate in intact and castrated male rats. Biol Reprod 1993; 48: 867 - 873

${ }^{36}$ Wilson RC, Knobil E. Acute effects of $N$-methyl-D,L-aspartate on the release of pituitary gonadotropins and prolactin in the female rhesus monkey. Brain Res 1982; 248: 177 - 179

${ }^{37}$ Zanisi M, Galbiati M, Messi E, Martini L. The anterior pituitary gland as a possible site of action of kainic acid. Proc Soc Exp Biol Med 1994; 206: $431-437$ 